\title{
Editorial Foreword 71.1 (February 2012)
}

\section{Our Cover}

Photograph of a Shanghai bookstore taken by the Editor in 2003. The shop stands (or perhaps stood, as given how quickly Shanghai is changing, it may have closed by now) on Fuzhou Road, a few blocks west of the Huangpu River, very close to the city's famous Bund. Fuzhou Road has a long association with literature and is sometimes referred to as Shanghai's "culture" street. The image thus speaks both to China's contemporary orientation toward the future (through the shop's name) and also to its literary traditions (through its location), tying it to both of the essays that open this issue.

\section{Trends}

We begin with a trio of interconnected essays that, while written in a manner to engage scholars working on varied parts of Asia, explore issues and publications specific to contemporary China. In the first, "Finding a Place: Mainland Chinese Fiction in the 2000s," Julia LovelL, a cultural historian and translator of short stories and novels, surveys the literary landscape of the People's Republic of China at the start of the $21^{\text {st }}$ century. Moving between highbrow, lowbrow and middlebrow works, she limns a set of contradictory developments. Lovell describes the last decade as a period when the Internet has trigged "an international revolution of the reader-writer relationship" that has altered the nature of literary endeavors in China and many other places as well. She notes that the world of Chinese literature has been "enriched by new expressive and publishing opportunities offered by the growth of new digital media” yet simultaneously "impoverished by the premature exodus of young, gifted writers from fiction, to film, blogging, journalism and celebrity culture," all the while continuing to contend with "ongoing political constrictions on literary freedom." Her essay should have value both to those working on contemporary China and also readers curious about getting brought up to speed on what Chinese contributors to varied literary genres have been publishing in the last decade.

The second piece, political scientist William A. Callahan's "Sino-speak: Chinese Exceptionalism and the Politics of History," surveys the burgeoning scholarly and popular literature on China's rise. It addresses influential efforts that are being made to come to terms with the vaunted "grand shift of power from the West to the East" that is currently underway (at least according to many commentators). In particular, Callahan is interested in the way that a 
cluster of authors have been trying to connect elements of China's past (real and imagined) to its present situation (economic and political) and its future prospects (as a country that some think might replace America's as the world's leading power). He zeroes in on how these writers define and defend the claim that "China has its own modernity" and as a result is "building its own road" to a new era in world history. Dividing authors up into provocatively titled categories ("The New Orientalists" is the subheading he gives for part of his review essay), Callahan draws attention to differences as well as similarities among the approaches taken in books by the likes of When China Rules the World (New York: Penguin Press, 2009) author Martin Jacques and Harmony and War: Confucian Culture and Chinese Power Politics (New York: Columbia University Press, 2011) author Yuan-kang Wang. "People in China and around the world," Callahan writes, are "asking about Beijing's plans for the future," so it is a propitious moment to explore some of the main answers that those concerned with international relations, in the policy and scholarly worlds, are giving to this query.

Completing the three-part look at Chinese themes is Christopher LuPKe, who uses a recent JAS review-Emily Baum's thoughtful assessment of Yomi Braester's Painting the City Red: Chinese Cinema and Urban Conflict (70.2) as a jumping off point for a spirited commentary on just what scholars should and should not include in "China" when addressing developments in "Chinese literature," "Chinese film," and so on. He argues passionately, contra Baum (and by implication at least contra one or both of the preceding essays in the current issue), that we miss out on valuable opportunities when we discuss contemporary "China" with little or no reference to what is going on in Taiwan. "Overshadowed by its massive cousin just to the West" that island may be, Lupke notes, but it has been and remains a "bastion of great intellectual activity on all disciplinary fronts," and as such deserves to be included in discussions of "Chinese" trends (something that he praises Braester for doing in Painting the City Red). Lupke backs up his case by drawing attention to some recent books that, like Braester's, have gone against the grain of putting Taiwan and the mainland in different categories. These works, while not ignoring the very real contrasts between mainland and Taiwan developments, demonstrate the gains to be made by taking an approach that moves "beyond political boundaries" in looking simultaneously at cultural activities occurring on opposite sides of the strait.

\section{Research Articles}

This issue does not have any "Asia Beyond the Headlines" essays, but the first research article, Robin JefFrey and Assa Doron's "Mobile-izing: Democracy, Organization and India's First 'Mass Mobile Phone' Elections," is similar to one, both in style and focus. Written in 2011, it provides a valuable framework for looking ahead to and making sense of the 2012 elections scheduled for Uttar Pradesh, which the authors note is not only "the largest state in India's federation" but so "populous that if it were sovereign, it would the sixth 
largest country in the world." Their main interest is in the significance that the widespread availability of mobile phones made in altering political equations and strategies in the 2007 Uttar Pradesh elections. At a time when discussions of new media and politics often focus on the Internet (the case, for example, in the exchange between Leibold and Yang on China and cyberspace that appeared in JAS 70.4), Jeffrey and Doron provide a useful reminder of how important cell phones can be in transforming a political terrain. We invite you to take a look at the web page for this issue on Cambridge Journals Online http://journals.cambridge.org/action/displayJournal?jid=JAS, for the authors' photos illustrating the piece, listed as "supplementary figures" under the article entry.

This stand-alone essay on recent events is followed by a forum that takes us back in time to the middle of the last century, albeit in order to discuss moral dilemmas of clear relevance for earlier and later periods. The centerpiece of the symposium is "Choosing to Collaborate: Yi Kwang-su and the Moral Subject in Colonial Korea," written by John Whittier Treat, a specialist in Japanese literature. Treat's essay takes as its point of departure a shift in scholarly discussions of Japanese imperial control of Korea. According to Treat, "students of Japan's history in the peninsula no longer easily speak of collaboration as a personal moral failure, but instead as a structural feature of modernity in that colonial world." This, Treat claims, is deeply problematic: advances in our understanding of the complexities of Asian colonial projects should not, he insists, make it impossible for us to adapt and apply to Korean cases the methods and "ethical theories" developed to analyze collaboration in Europe during World War II. Two responses to Treat's strongly argued essay follow. The first is by ТімотнY BROoK, a scholar whose influential study of collaboration in wartime China is among the works with which Treat takes issue, and the second by Michael D. SHIN, a specialist in Korean studies who has written about Yi Kwang-su in the past. After Brook's "Hesitating before the Judgment of History" and Shin's "Yi Kwang-su: The Collaborator as Modernist against Modernity," comes a rejoinder by Treat, "Seoul and Nanking, Baghdad and Kabul: A Response to Timothy Brook and Michael Shin," which concludes an engaging and thought-provoking forum that I hope will end up being argued about and taught in classes (I know I will look forward to having my own students grapple with the issues it raises).

While Treat and his critics take us from Asia to other parts of the world via the issues they address and comparisons they explore, the next article, HenrietTA Harrison's "Rethinking Missionaries and Medicine in China: The Miracles of Assunta Pallotta, 1905-2005," does this via a transnational career and equally transnational posthumous cult. At the center of Harrison's story is an Italian missionary who died in China and inspired healing cults after death in both that country and her native land. As intriguing as the details of the tale are, "Rethinking Missionaries and Medicine" is more than just a lively foray into microhistory, for it uses the case of Assunta Pallotta to call into question some common assumptions about the interplay between Chinese and Western medical traditions, which have taken root, Harrison claims, in large part because so much more attention has been paid to male than to female actors. 


\title{
4 Editorial Foreword
}

Next comes an article that is similarly attentive to the gendered dimensions of phenomena, but shifts our focus from China and Europe to South Asia. In "Resurrecting Seva (Social Service): Dalit and Low-caste Women Party Activists as Producers and Consumers of Political Culture and Practice in Urban North India," Manuela Ciotti uses the lens of gender and assumptions about proper male and female roles to illuminate the "constraints and disruptive potential" of an important set of members of the urban poor. In the process, the author sheds new light on issues ranging from the dynamics of political patronage to the workings of civil society in Indian cities.

The final research article of the issue, which is followed by our usual array of book reviews, is a look at attitudes toward cars and driving in Japan. Written by Joshua Hotaka Roth and titled "Heartfelt Driving: Discourses on Manners, Safety, and Emotion in Japan's Era of Mass Motorization," this essay notes that: "Automobility, or the individualized control of motorized transport, affords greater flexibility and a sense of freedom, yet involves the potential for a great number of accidents." There are varied ways that cultures, nations, and subcultures can confront this mixture of new possibilities and new dangers, as Roth shows, through his fascinating overview of the Japanese case, drawing on everything from the questions on driving tests to "newspaper and magazine articles from the 1960s and "70s [that] criticized aggressive driving and urged people to give way to each other (yuzuri-ai) on the road."

\section{Forthcoming Articles in JAS 71:2 (May 2012)}

\author{
Asia Beyond the Headlines
}

Living with Uncertainty After March 11, 2011

JORDAN SAND

Radioactive Rain and the American Umbrella

Yoshimi Shun'ya, Translated by Shi-Lin Loh

Japanese Seismicity and the Limits of Prediction

Greg Clancey

The Ongoing Disaster

Alexis Dudden

Trends

Domination and Dereliction: Exploring the State's Roles in Burma Jacques P. Leider 
Research Articles

Power, Civil Society, and an Inchoate Politics of the Daily in Burma/Myanmar Elliott Prasse-Freeman

Moral Imperatives: South Korean Studenthood and the April Revolution of 1960 Charles Kim

What is this "Chinese" in Overseas Chinese?: Sojourn Work and the Place of China's Minority Nationalities in Extraterritorial Chinese-ness

CHristopher VASANTKUMAR

Articulating Regionalism through Popular Music: The Case of Nauchami Narayana in the Uttarakhand Himalayas

Stefan Fiol

An Ever-contested Poem: The Classic of Poetry's "Hanyi" and the Sino-Korean History Debate

JaE-HOON SHIM 